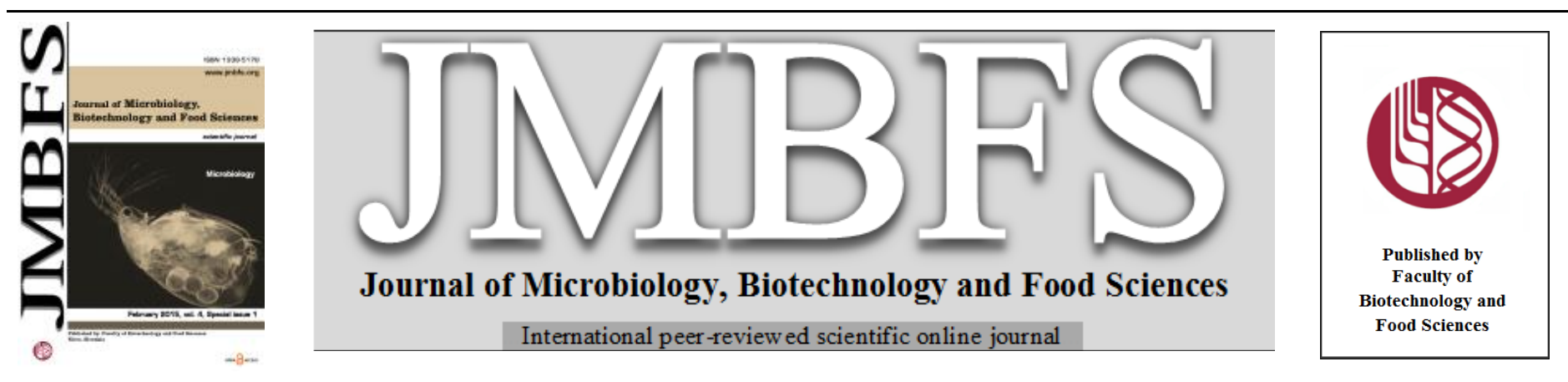

\title{
ISOLATION AND CHARACTERIZATION OF STREPTOMYCES RISHIRIENSIS (VY31) WITH ANTIBIOTIC ACTIVITY AGAINST VARIOUS PATHOGENIC MICROORGANISMS
}

\author{
Ivana Charousová*1, Soňa Javorekovál , Joachim Wink ${ }^{2}$ \\ Address(es): Dipl.-Ing. Ivana Charousová, \\ ${ }^{1}$ Slovak University of Agriculture in Nitra, Faculty of Biotechnology and Food Sciences, Department of Microbiology, Tr. A. Hlinku 2, \\ 94976 Nitra, Slovakia, +421 376414433 \\ ${ }^{2}$ Helmholtz Centrum for Infection Research, Microbial Strain Collection Group, Inhoffenstraße 7, 38124 Braunschweig, Germany.
}

*Corresponding author: ivanacharousova@gmail.com

doi: 10.15414/jmbfs.2015.4.special1.23-27

ARTICLE INFO

Received 13. 11. 2014

Revised 17. 12. 2014

Accepted 20. 12. 2014

Published 2. 2. 2015

Regular article

open $O$ access

\begin{abstract}
Actinomycete strain VY31 was isolated from agriculture soil of region Východná, Slovakia. Morphological, physiological and biochemical studies indicated that this isolate belongs to the genus Streptomyces. The 16S rRNA sequence data supported the assignment of the isolate to the genus Streptomyces rishiriensis (sequence similarity 97\%). Tested isolate was able to produce melanin dark pigment and exopigments on ISP6, ISP7 and SSM+T cultivating media. The optimal pH range was from 6-8 and optimal temperature at $30{ }^{\circ} \mathrm{C}$. The strain exhibited salt tolerance up to $5 \%$ and utilized the carbon sources such as glucose, arabinose, xylose, inositol, mannose, fructose, rhamnose and rafinose. Using ApiZym ${ }^{\circledR}$ stripes, the highest production of enzymes was determined for phosphatase alkaline, leucinearylamidase, valinearylamidase, phosphatase acid, naphtol-AS-BI-phosphohydrolase, galactosidase and glucosidase (>40 nmol). According to ApiCoryne ${ }^{\circledR}$ results, positive reaction was confirmed in case of esculin, alkaline phosphatase, and this strain was also able to hydrolyze gelatine. Minimum Inhibitory Concentration (MIC) of the purified extract of isolate was evaluated against Gram-positive bacteria Staphylococcus aureus and Enterococcus faecium, Gram-negative bacteria Escherichia coli and Pseudomonas aeruginosa and against yeast Candida albicans. On the basis of MIC results, strain VY31 had noticeable antibacterial activity against Staphylococcus aures N315 (MRSA) from collection database of University Hospital in Hamburg, Germany. This isolate could be used in the development of new antibiotics for pharmaceutical purposes.
\end{abstract}

Keywords: Soil, Streptomyces sp., minimal inhibitory concentration, pathogenic microorganisms

\section{INTRODUCTION}

Microorganisms are the main colonizers of the earth, bestowed with inherent physiological and functional diversity and have found applications in agriculture, medicine, industry and environment. Among the various industrially important microorganisms, actinomycetes are of prime importance and are primarily recognized as organisms of academic curiosity (Rana et Salam, 2014) because of its wide antimicrobial activity (Thakur $\boldsymbol{e t}$ al., 2007). Actinomycetes are grampositive, filamentous (Holt et al., 2000; Varghese et al., 2012), free-living, saprophytic bacteria (Rahman et al., 2011) with high $\mathrm{G}+\mathrm{C}$ contents in DNA inhabiting mainly the soils (Deepika et Kannabiran, 2009), where decompose organic matter, especially biopolymers such as lignocellulose, starch, and chitin (Crawford et $\boldsymbol{a l}$., 1993). From the 22,500 biologically active compounds that have obtained from microbes, $45 \%$ are produced by actinomycetes, $38 \%$ by fungi, and $17 \%$ by unicellular bacteria (Berdy, 2005). The species belong to the genus Streptomyces constitute $50 \%$ of the total population of soil actinomycetes and are well known for producing a variety of bioactive secondary metabolites including antibiotics, immunomodulators, anticancer drugs, antiviral drugs, herbicides, and insecticides (Sanglier et al., 1993). Screening of microorganisms for the production of novel secondary metabolites has been intensively pursued for many years by scientists (Oskay et al., 2004), due to intensely increasing resistance of clinically important bacterial strains (Sahin, 2003; Patel et al. 2014). Actinomycetes and their bioactive compounds show antibacterial and antifungal activity against various pathogens and multi drug resistant pathogens e.g. methicillin-resistant Staphylococcus aureus, Pseudomonas aeruginosa (Singh et al., 2012), Escherichia coli, Enterococcus faecium (Sharma et al., 2011) and also against yeasts e.g. Candida genera (Spadari et al., 2013). Thus, it is necessary to continue antimicrobial screening and evaluate and identify the potential of microbial taxa especially against drug-resistant bacteria (Kurtboke, 2005).

The present investigation describes the isolation, morphological, physiological, biochemical and genotypic characterization of Streptomyces rishiriensis actinomycete strain with antibiotic activity against various pathogenic microorganisms.

\section{MATERIAL AND METHODS}

The tested actinomycete strain was isolated from soil sample collected at region Východná (geographical coordinates: latitude $49^{\circ} 4^{\prime} \mathrm{N}$, longitude $19^{\circ} 54^{\prime} \mathrm{E}$ ), Slovakia, using classical plate dilution method on Pochon medium (Korzeniewska et al., 2009) complemented with nystatin $(50 \mu \mathrm{g} / \mathrm{ml})$. After gently rotating, the plate was incubated at $28^{\circ} \mathrm{C}$ for 7 days. Strain was transferred from mixed culture of the plate into selective yeast extract-malt extract medium (Shirling et Gottlieb, 1966) for purification, identified on the basis of various criteria and determined for inhibition activity against selected pathogenic microorganisms.

\section{Morphological characterization}

Standard media for colony description were described by Shirling et Gottlieb (1966) in International Streptomyces project (ISP). The morphological characteristics were observed by culturing isolate on ISP2-ISP7 media. For morphological characteristic four parameters were used - growth, reverse colors, colors of aerial mycelium and colors of soluble pigments. The colors were described by the RAL-code. ISP6 and ISP7 media were also used together with the synthetically Suter medium (Suter, 1978) with and without tyrosine for the detection of melanin production. The pigment production of test strain was controlled after 5, 10 and 14 days and recorded by using "+" for a visible formation or "_"for none. For the light microscopic classification of the strain, well grown agar plate with GYM medium (Větrovský $\boldsymbol{e t}$ al., 2014) was used for observation of spore chain morphology.

\section{Physiological testing}

The physiological testing holds four different approaches for the characterization of actinobacteria strains, including optimal $\mathrm{pH}$ and temperature for growth, resistance toward sodium chloride and utilization of various carbon sources. $\mathrm{pH}$ tolerance was tested in tubes with liquid ISP2 medium at $\mathrm{pH}$ levels of 2, 3, 4, 5, $6,7,8,9$, and 10. After 5-7 days of incubation was documented visible growth. 
For determination of optimal temperature ISP2 agar plates were incubated at 25, 30,45 and $60^{\circ} \mathrm{C}$. Sodium chloride tolerance was tested on microtiter plates (sixwell) using a technique based on the method of to Kutzner (1981). The growth of strain was determined on medium (casein peptone $-10.0 \mathrm{~g} / \mathrm{L}$, yeast extract $5.0 \mathrm{~g} / \mathrm{L}$, agar $-20.0 \mathrm{~g} / \mathrm{L}$, deionized water $-1000 \mathrm{ml}$ ) with $0,2.5,5,7.5$ and $10 \%$ of sodium chloride. Utilization of different carbon sources was determined on the basis of Shirling $\boldsymbol{e t}$ Gottlieb (1966) methodology using a microplate technique with twelve well plates. Physiological tests included ability to utilize 10 differen carbon sources (arabinose, cellulose, fructose, glucose, inositol, mannitol, raffinose, rhamnose, sucrose and xylose). The evaluation was carried out using "" for lesser growth like in case of negative control (plate without $\mathrm{C}$ - source) and $"+"$ if growth was similar to positive control (plate with addition of glucose).

\section{Biochemical characteristic with Api ${ }^{\circledR}$ stripes}

For detection of enzymes we used two different Api ${ }^{\circledR}$ systems - ApiCoryne ${ }^{\circledR}$ and ApiZym ${ }^{\circledR}$. For conducting the Api ${ }^{\circledR}$ tests, culture was grown in shaking flask with GYM medium for one week and after that the strain was inoculated followed by manufacturer's manual. Stripes were incubated 24 hours $\left(30^{\circ} \mathrm{C}\right)$. After incubation we added one drop of ZYM A and one drop of ZYM B reagents to each cupule of ApiZym ${ }^{\circledR}$ stripes. In case of ApiCoryne ${ }^{\circledR}$ we added one drop of NT1+NT2 reagents to the first cupule, PYZ reagent to the second cupule and one drop of ZYM A and ZYM B to the next six cupules. The rest of cupules were not filling with any reagents. We let the colors develop and after five minutes we evaluated stripes according to manual criteria.

\section{S rRNA analysis}

Genomic DNA was isolated according to Sambrook et al. (1989) methodology. The quality of isolated DNA was determined electrophoretic on $2 \%$ agarose gel and visualized by Gel Logic 212 PRO Imaging System (Carestream Health, Inc. USA). The isolated DNA was amplified by PCR reaction using primers according to Cook et Meyers (2003). Reaction mixture was made in total volume of $50 \mu \mathrm{l}$. Each reaction contained $5 \mu$ of $10 \times$ DreamTaq Green PCR buffer, $5 \mu$ of 2 mmol.dm ${ }^{-3} \mathrm{dNTP}, 2 \mu \mathrm{l}$ of each $10 \mu$ mol.dm ${ }^{-3}$ primer, 0,3 $\mu \mathrm{l}$ Taq DNA polymerase and $0,5 \mu \mathrm{l}$ of template DNA (approximately $20 \mathrm{ng}$ ). The PCR reaction ran in thermo cycler Biometra $\mathrm{T}$ Personal under the following conditions: $95{ }^{\circ} \mathrm{C}$ for $3 \mathrm{~min}, 40$ cycles of $95{ }^{\circ} \mathrm{C}$ for $30 \mathrm{sec}, 56{ }^{\circ} \mathrm{C}$ for $30 \mathrm{sec}, 72$ ${ }^{\circ} \mathrm{C}$ for $90 \mathrm{sec}$ and final extension at $72{ }^{\circ} \mathrm{C}$ for $10 \mathrm{~min}$. PCR products were purified using Exonuclease I and Thermosensitive Alkaline Phosphatase according to the manufacturer's instructions and send for sequencing in MacroGen company, South Korea. The similarity and homology of the 16S rRNA gene sequence was analysed with the similar existing sequences available in the data bank of National Center for Biotechnology Information (NCBI) using BLAST search (http://www.ncbi.nlm.nih.gov/BLAST)

\section{Preparation of extract}

For the liquid cultivation a single colony of the strain was transferred in 5254 medium (Wink et al., 2013) for metabolite production using a sterile inoculating loop. The culture was incubated at $30^{\circ} \mathrm{C}$ for $5-10$ days at $160-180 \mathrm{rpm}$ on the shaker. $20 \mathrm{ml}$ of 5 days old culture were mixed with $20 \mathrm{ml}$ of ethyl acetate in a 50 $\mathrm{ml}$ Falcon tube. After a 12 min shaking step the sample was centrifuged at 9000 rpm for $10 \mathrm{~min}$ and the upper phase was transferred into a $50 \mathrm{ml}$ round bottom flask. At about $40^{\circ} \mathrm{C}$ the ethyl acetate was evaporated in a rotary evaporator (Heidolph). Finally, the extract was solved in $1 \mathrm{ml}$ of ethyl acetate: acetone: methanol (1:1:1) and centrifuged at $14000 \mathrm{rpm}$ for $10 \mathrm{~min}$.

\section{Tested microorganisms and determination of antimicrobial activity}

Tested microorganisms were obtained from Microbial Strain Collection Group (MISG) of Helmholtz Centrum for Infection Research (HZI) in Braunschweig, Germany. The selected pathogenic microorganisms used in antimicrobial study were Escherichia coli (DSM 116), Escherichia coli WT3 (resistance on chinolone), Staphylococcus aureus (Newman), Staphylococcus aureus N315 (MRSA), Candida albicans (DSM 1665), Pseudomonas aeruginosa (DSM 19882), Enterococcus faecium (DSM 20477) and Enterococcus faecium (DSM 17050).

Minimal inhibitory concentration of active ethyl acetate crude extract of isolates was determined by serial dilution method. The whole experiment was conducted in 96-well plates. Initially, the correspondent inoculation volume of the test strains was transferred into $20 \mathrm{ml}$ of the suitable media (Table 1). $150 \mu \mathrm{l}$ of the test culture medium was transferred into each well and additional $150 \mu 1$ in wells of the first row. Afterwards (A12) was used as negative control by adding $20 \mu 1$ of acetate: acetone: methanol $(1: 1: 1)$, whereas the other places in the first row were inoculated with $20 \mu \mathrm{l}$ of the raw extracts. Subsequently the first row was mixed and $150 \mu \mathrm{l}$ of the mixture was transferred into the new row (B). This procedure was taken out until the last row was reached. Data about optimal concentration of tested microorganisms were obtained from MISG of HZI after long investigations.
Table 1 Cultural conditions of selected pathogenic microorganisms used for detection of minimal inhibitory concentration

\begin{tabular}{lccc}
\hline $\begin{array}{l}\text { Tested } \\
\text { microorganisms }\end{array}$ & $\begin{array}{c}\text { Cultivating } \\
\text { medium (20 ml) }\end{array}$ & $\begin{array}{c}\text { Amount } \\
(\boldsymbol{\mu l})\end{array}$ & $\begin{array}{c}\text { Temperature } \\
\text { of incubation } \\
\left({ }^{\circ} \mathbf{C}\right)\end{array}$ \\
\hline $\begin{array}{l}\text { Escherichia coli } \\
\text { (DSM 116) }\end{array}$ & MHB & 126 & 37 \\
\hline $\begin{array}{l}\text { Escherichia coli } \\
\text { (WT3) }\end{array}$ & MHB & 106 & 37 \\
\hline $\begin{array}{l}\text { Staphylococcus } \\
\text { aureus } \text { (Newman) }\end{array}$ & MHB & 108 & 37 \\
\hline $\begin{array}{l}\text { Staphylococcus } \\
\text { aureus } \text { (N315) }\end{array}$ & MHB & 104 & 37 \\
\hline $\begin{array}{l}\text { Candida albicans } \\
\text { (DMS 1665) }\end{array}$ & MYC & 123 & 30 \\
\hline $\begin{array}{l}\text { Pseudomonas } \\
\text { aeruginosa } \text { (DSM } \\
\text { 19882) }\end{array}$ & MHB & 136 & 37 \\
\hline $\begin{array}{l}\text { Enterococcus faecium } \\
\text { (DSM 20477) }\end{array}$ & TSB & 216 & 37 \\
\hline $\begin{array}{l}\text { Enterococcus faecium } \\
\text { (DSM 17050) }\end{array}$ & TSB & 218 & 37 \\
\hline Legend: MHB - Mueller Hinton Broth, MYC- Mycosal medium, TSB - Tryptic Soy Broth
\end{tabular}

\section{RESULTS AND DISCUSSION}

Genus Streptomyces is considered as the most secondary metabolite producing genus of actinomycetes. For this reason an attempt to isolate, identify and study antimicrobial activity of Streptomyces species from natural soil habitats of microorganisms was screened.

The selected actinomycete strain VY31 exhibited typical morphological characteristics of the genus Streptomyces (slow growing, chalky, heaped and folded colony with aerial and substrate mycelium of different colors). In addition, streptomyces strains possessed an earthy odor (Suneetha, 2011). Morphological and micro morphological observation of the strain revealed that vegetative and aerial mycelium were abundant, well development and fragmented with rod shaped spores. Sporophore morphology of the strain grown on GYM medium for seven days showed rectus-flexibilis pattern. The cultural characteristics of the strain are represented in Table 2. The strain VY31 exhibited good growth on five from eight used media. The colors of substrate and aerial mycelium varied depending on medium (Figure 1). Sivakumar (2001) reported that the cultura characteristics could be used as markers by which an individual can be recognized.

Table 2 Morphological characterization of VY31 strain on different cultivating media

\begin{tabular}{|c|c|c|c|c|}
\hline Medium & $\begin{array}{l}\text { Reverse } \\
\text { color }\end{array}$ & $\begin{array}{c}\text { Color } \\
\text { of aerial } \\
\text { mycelium }\end{array}$ & $\begin{array}{l}\text { Color of } \\
\text { diffusible } \\
\text { pigments }\end{array}$ & $\begin{array}{l}\text { Speed } \\
\text { of } \\
\text { growth }\end{array}$ \\
\hline $\begin{array}{l}\text { Yeast malt agar } \\
\text { (ISP2) }\end{array}$ & $\begin{array}{l}\text { Sand } \\
\text { yellow }\end{array}$ & No growth & - & Good \\
\hline $\begin{array}{l}\text { Oatmeal agar } \\
\text { (ISP3) }\end{array}$ & Beige & Light ivory & - & Good \\
\hline $\begin{array}{l}\text { Inorganic salt- } \\
\text { starch agar (ISP4) }\end{array}$ & Ivory & No growth & - & Good \\
\hline $\begin{array}{l}\text { Glycerol } \\
\text { asparagine agar } \\
\text { (ISP5) }\end{array}$ & $\begin{array}{l}\text { Light } \\
\text { ivory }\end{array}$ & No growth & - & Sparse \\
\hline $\begin{array}{l}\text { Peptone yeast } \\
\text { extract iron agar } \\
\text { (ISP6) }\end{array}$ & $\begin{array}{l}\text { Terra } \\
\text { brown }\end{array}$ & Agate grey & Pale brown & Sparse \\
\hline $\begin{array}{l}\text { Tyrosine agar } \\
\text { (ISP7) }\end{array}$ & $\begin{array}{c}\text { Pale } \\
\text { brown }\end{array}$ & Agate grey & Pale brown & Good \\
\hline $\begin{array}{l}\text { Suter medium with } \\
\text { tyrosine }(\mathrm{SSM}+\mathrm{T})\end{array}$ & $\begin{array}{l}\text { Signal } \\
\text { black }\end{array}$ & No growth & $\begin{array}{c}\text { Terra } \\
\text { brown }\end{array}$ & Good \\
\hline $\begin{array}{l}\text { Suter medium } \\
\text { without tyrosine } \\
\text { (SSM-T) }\end{array}$ & $\begin{array}{l}\text { Light } \\
\text { ivory }\end{array}$ & No growth & - & Sparse \\
\hline
\end{tabular}

Baskaran et al. (2011) studied a high potential antibacterial actinomycete, which was cultured on six different culture media. This isolate mostly developed dark grey to white colored aerial mycelium and coffee brown colored substrate mycelium. In study of Naine et al. (2012) the colonies of actinomycetes with powdery appearance had a characteristic feature of concave, convex, flat surface with different colors from grey, white, pink, cream to yellowish. Thus, we can conclude that the nutrient compositions of the medium greatly influenced the growth and morphology of actinomycetes. 
Part of the morphological characteristic includes also ability to produce darkbrown substances in the culture media, generally referred to as melanin or melanoid pigments. Melanin is negatively charged composed of multi-functional polymer and polyphenolic compound that is produced by various microorganisms by fermentative oxidation (Dastager $\boldsymbol{e t}$ al., 2006) and have the radioprotective and antioxidant properties that can effectively protect the living organisms from ultraviolet radiation (Vinarov et al., 2002). Streptomyces species also produce brown exopigments on agar media, which mostly but not always correlate with the appearance of melanin pigment with tyrosinase activity (Claus et Decker 2006). Strain VY31 produced melanin pigment on SSM+T medium and brown exopigments on ISP6 and ISP7 media (Figure 1)
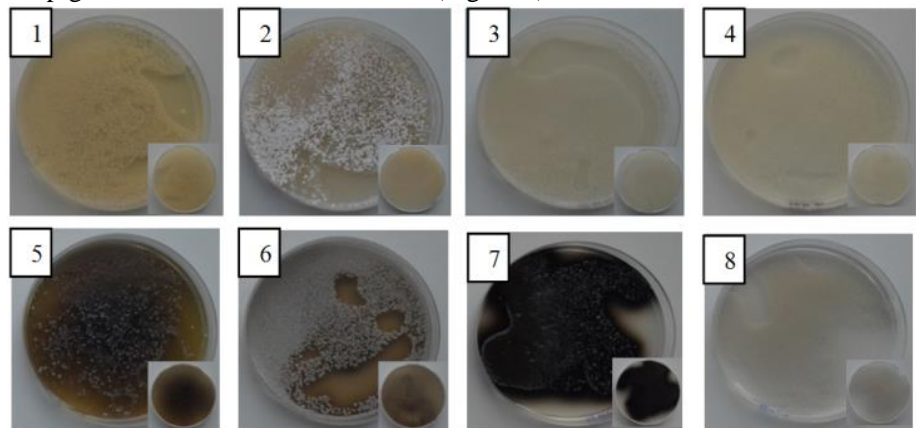

Figure 1 Morphological characteristic of VY31 strain on 1-ISP2, 2-ISP3, 3-ISP4 4-ISP5, 5-ISP6, 6-ISP7, 7-SSM+T, 8-SSM-T media

Antonova-Nikolova et al. (2006-2007) found out, that Streptomyces sp. strain 34-1 synthesizes melanin pigment only on the ISP6 medium. Some authors also reported that melanin pigments produced by Streptomyces species have antimicrobial activity, for example against Aspergillus niger (Ali et al. 2011).

The physiological tests are indispensable tools for classification and identification of actinomycetes and influencing the growth rate of actinomycetes (Shimizu et al., 2000). Streptomycetes are known to prefer neutral to alkaline environment $\mathrm{pH}$, optimal growth $\mathrm{pH}$ range being 6.5-8 (Locci, 1989). Growth of the strain VY31 occurred in the $\mathrm{pH}$ range of 6-8 with optimum growth at $\mathrm{pH}$ 7.The optimal temperature being $30{ }^{\circ} \mathrm{C}$. For most actinomycetes, the optimum growth temperature is 23-37 ${ }^{\circ} \mathrm{C}$, whereas Goodfellow et Williams (1983) reported that most of the actinomycetes behave as mesophiles with an optimum growth $30^{\circ} \mathrm{C}$. The strain exhibited salt tolerance up to $5 \%$ (Table 3 ), but results of Cai (2009) indicated, that actinomycetes are also able to grow on media with 7.0, 10 and also $15 \%$ of $\mathrm{NaCl}$. $\mathrm{NaCl}$ tolerance of actinomycetes studied by Naine et al. (2012) was only $1 \%$ of $\mathrm{NaCl}$. Utilization of carbon sources by the strain also could be used as an aid for species determination (Pridham et Gottlieb, 1948). The strain efficiently utilized the carbon sources such as glucose, arabinose, xylose, inositol, mannose, fructose, rhamnose and rafinose, but not utilized sucrose and cellulose (Table 4). The similar results found out Baskaran et al. (2011); Naine et al. (2012) and Pandey et al. (2005).
Table 3 Physiological testing of strain VY31

\begin{tabular}{cccc}
\hline \multicolumn{4}{c}{ Observed parameters } \\
\hline $\mathbf{0 \% ~ N a C l}$ & Growth & $\begin{array}{c}\text { Formation of } \\
\text { aerial mycelium }\end{array}$ & $\begin{array}{c}\text { Diffusible } \\
\text { pigment }\end{array}$ \\
$\mathbf{2 , 5 \% ~ N a C l}$ & + & + & + \\
$\mathbf{5 \% ~ N a C l}$ & + & + & + \\
$\mathbf{7 , 5 \% ~ N a C l}$ & + & - & - \\
$\mathbf{1 0 \%} \mathbf{N a C l}$ & - & - & - \\
Glucose & - & - & - \\
Arabinose & + & + & - \\
Sucrose & + & + & + \\
Xylose & - & - & - \\
Inositol & + & + & - \\
Mannose & + & + & - \\
Fructose & + & + & - \\
Rhamnose & + & + & + \\
Rafinose & + & + & + \\
Cellulose & + & + & - \\
\hline
\end{tabular}

A huge enzymatic variability was discovered within the range of isolated streptomycetes. We found out, that our isolate produce phosphatase alcaline, leucinearylamidase, valinarylamidase, phosphatase acid, naftol-AS-BIphosphohydrolase, galactosidase and glucosidase in important values $(>40 \mathrm{nmol})$ (Table 4). Negative activity was observed only for lipase, chymotrypsin, galactosidase, glucuronidase, $\mathrm{N}$-acetyl-glucoseamidase, mannosidase and fucosidase. On the basis of ApiCoryne $\mathbb{B}$ results we found out, that our isolate produce only phospahatase alcaline, esculin and also hydrolysed gelatin (Table 5). In study of Khan et al. (2010) strain Streptomyces tateyamensis demonstarted positive activity for $N$-acetyl- $\beta$-glucosaminidase, acid phosphatase, alkaline phosphatase, $\alpha$-chymotrypsin, gelatin hydrolysis, $\alpha$-glucosidase, $\beta$-glucosidase, leucine arylamidase, $\alpha$-mannosidase, naphthol-AS-BI-phosphohydrolase, pyrazinamidase, pyrolidonyl arylamidase, trypsin and urease. Negative activity was observed for esterase, esterase lipase, $\alpha$-fucosidase, $\alpha$-galactosidase, $\beta$ galactosidase, $\beta$-glucuronidase and lipase. Nagai et al. (2011) reported positive enzymatic activity of Streptomyces aomiensis for acid phosphatase, catalase, $\beta$ glucosidase, leucine arylamidase, $N$-acetyl- $\beta$-glucosaminidase, naphthol-AS-BIphosphohydrolase, pyrazinamidase and nitrate reduction and weakly positive for cystine arylamidase, pyrrolidonyl arylamidase and valine arylamidase, but negative for alkaline phosphatase, esterase, esterase lipase, $\alpha$-chymotrypsin, $\alpha-$ fucosidase, $\alpha$ - and $\beta$-galactosidase, $\beta$-glucuronidase, $\alpha$-glucosidase, $\alpha$ mannosidase, lipase, trypsin, urease and gelatin hydrolysis.

Using ApiZym ${ }^{\circledR}$ and ApiCoryne ${ }^{\circledR}$ stripes is providing the advantage of easy and fast determination between two isolates showing significant appearance by means of the differences in their enzyme profiles. On the other hand, there are doubts about usability of this method as a taxonomic tool (Vítězová, 2013). Reliable identification of isolated actinomycetes from soils should involve using a polyphasic taxonomic approach and employing a wide variety of phenotypic and molecular techniques.

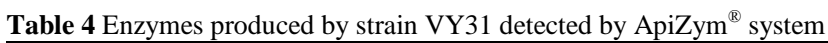

\begin{tabular}{|c|c|c|c|}
\hline & ApiZym system & & \\
\hline No. & Enzyme & Substrate & Amount of enzyme (nmol) \\
\hline 2 & Phosphatase alkaline & 2-naphtyl phosphate & $>40$ \\
\hline 3 & Esterase (C4) & 2-naphtyl butyrate & 10 \\
\hline 4 & Esterase lipase (C8) & 2-naphtyl caprylate & 10 \\
\hline 5 & Lipase (C14) & 2-naphtyl myristate & 0 \\
\hline 6 & Leucinearylamidase & L-leucyl-2-naphthylamide & $>40$ \\
\hline 7 & Valinearylamidase & L-valyl-2-naphthylamide & $>40$ \\
\hline 8 & Cystinearylamidase & L-cystyl-2-naphthylamide & 20 \\
\hline 9 & Trypsin & N-benzoyl-DL-arginine-2-naphtylamide & 5 \\
\hline 10 & Chymotrypsin & N-glytaryl-phenylalanine-2-naphtylamide & 0 \\
\hline 11 & Phosphatase acid & 2-naphtyl phosphate & $>40$ \\
\hline 12 & Naphtol-AS-BI-phosphohydrolase & Naphtol- AS-BI-phosphate & $>40$ \\
\hline 13 & Galactosidase & 6-Br-2-naphtyl-D-galactopyranoside & 0 \\
\hline 14 & Galactosidase & 2-naphtyl-D-galactopyranoside & $>40$ \\
\hline 15 & Glucuronidase & Naphtol-AS-BI-D-glucuronide & 0 \\
\hline 16 & Glucosidase & 2-naphtyl-D-glucopyranoside & $>40$ \\
\hline 17 & Glucosidase & 6-Br-2-naphtyl-D-glucopyranose & $>40$ \\
\hline 18 & $\mathrm{~N}$-acetyl-glucoseamidase & 1-naphtyô-N-acetyl-D-glucoseaminide & 0 \\
\hline 19 & Mannosidase & 6-Br-2-naphtyl-D-mannopyranoside & 0 \\
\hline 20 & fucosidase & 2-naphtyô-L-fucopyranoside & 0 \\
\hline
\end{tabular}


Table 5 Enzymatic activities tested by ApiCoryne ${ }^{\circledR}$ system

\begin{tabular}{|c|c|c|c|c|c|}
\hline Test & Reaction & Result & Test & Reaction & Result \\
\hline Nit & Nitrate reduction & - & Pyz & Pyrazinamidase & - \\
\hline PyrA & PyrrolidonylArylamidase & - & $\mathrm{Pal}$ & Alkaline phosphatase & + \\
\hline Gur & $\beta$-glucuronidase & - & Gal & $\beta$-galactosidase & - \\
\hline Glu & $\alpha$-Glucosidase & - & Nag & $\mathrm{N}$-acetyl- $\beta$-glucosamidase & - \\
\hline Esc & Esculin ( $\beta$ - Glucosidase) & + & Ure & Urease & - \\
\hline Gel & Gelatine (hydrolysis) & + & Glu & Glucose fermantation & - \\
\hline Rib & Ribose fermentation & - & $\mathrm{Xyl}$ & Xylose fermentation & - \\
\hline Man & Mannitol fermentation & - & Lac & Lactose fermentation & - \\
\hline $\mathrm{Sac}$ & Sucrose fermentation & - & Glyg & Glycogen fermentation & - \\
\hline
\end{tabular}

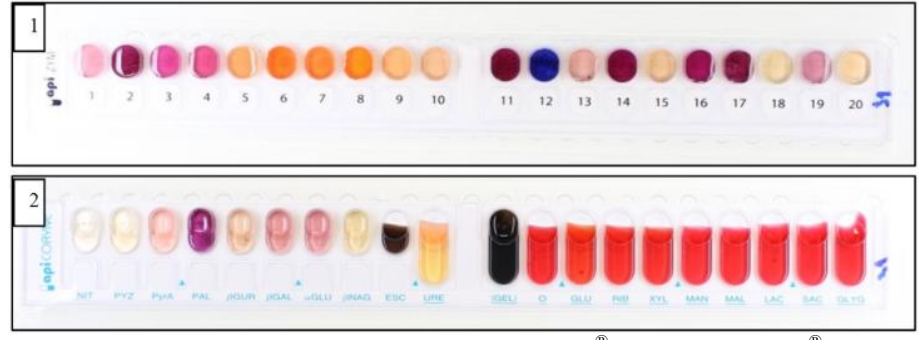

Figure 2 Visible enzymatic reactions of 1-ApiZym ${ }^{\circledR}$ and 2-ApiCoryne ${ }^{\circledR}$ stripes

For genotypic identification, specific primers - F1 (5'AGAGTTTGATCITGGCTCAG-3'; $\quad \mathrm{I}=$ inosine) and R5 (5'ACGGITACCTTGTTACGACTT-3') were used for amplification and sequencing the gene $16 \mathrm{~S}$ rDNA of the isolate VY31. The partial sequence was aligned and compared with all the 16S rRNA gene sequence available in the GenBank database by using the multisequence advanced BLAST comparison tool that is available in the website of National Centre for Biotechnology Information (Figure 3).

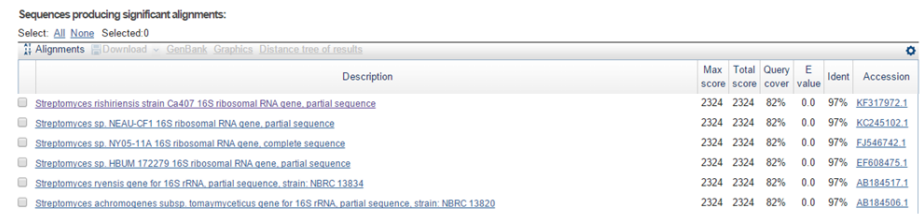

Figure 3 Sequence producing significant alignment for isolate VY31

The 16S rRNA sequence data supported the assignment of this isolate VY31 to the genus Streptomyces and species rishiriensis (Streptomyces rishiriensis strain Ca407)

\section{Antimicrobial activity of Streptomyces rishiriensis}

In the course of screening for novel antimicrobial substances (antibiotics) from soil samples, antibiotic-producing actinomycete cultures were recorded from soil samples taken in Východná, Slovakia. During our continuous search for novel antimicrobial metabolites of this region led to the isolation of actinomycetes isolate VY31 on Pochon medium by soil dilution plate technique. The MIC evaluation of the actinomycete isolate was performed against all the tested microorganisms by the dilution method (Table 6). The highest inhibition activity was observed against Staphylococcus aureus N315 (MRSA). Identification of novel antagonistic molecules is needed for MRSA due to emerging resistance, because multidrug resistant Staphylococcus aureus serves as a hospital borne pathogen and plays a dominant role in many clinical problems globally (Sharma et al., 2011). The choice of drugs against MRSA is very less due to their genetic alternation, enzyme variations and permeability changes. Due to harmful effects, there is a need to find out new drug molecules against MRSA (Parasa et al., 2011). Inhibitory activity of soil actinomycetes against MRSA recorded also Sharma et al. (2011) and Amirmozaffari et al. (2014) who found out, that three isolates (from 96 strains) with inhibition zones 28,17 and $15 \mathrm{~mm}$ in diameter inhibited this pathogen.
Table 6 Antimicrobial activity of selected strain against selected pathogenic bacteria and yeast

\begin{tabular}{|lc|}
\hline $\begin{array}{l}\text { Tested } \\
\text { microorganisms }\end{array}$ & $\begin{array}{c}\text { Maximum letter of inhibition } \\
\text { on MIC plates }\end{array}$ \\
\hline Escherichia coli (DSM 116) & A* \\
\hline Escherichia coli (WT3) & - \\
\hline Staphylococcus aureus (Newman) & C \\
\hline Staphylococcus aureus (N315) & F \\
\hline $\begin{array}{l}\text { Pseudomonas aeruginosa (DSM } \\
\text { 19882) }\end{array}$ & - \\
\hline Candida albicans (DSM 1665) & D \\
\hline Enterococcus faecium (DSM 20477) & A \\
\hline Enterococcus faecium (DSM 17050) & A \\
\hline
\end{tabular}

* Letter of lowest concentration of an antimicrobial that inhibited the visible growth of a tested microorganisms on MIC plate

Moderate inhibition activity was determined against Staphylococcus aureus (Newman) and Candida albicans (DSM 1665). Inhibition of Candida species growth was observed by many scientists (Bharti et al. (2010); Das et al. (2014); Anansiriwattana et al., (2006)). In contrast, strain VY31 showed weak inhibition activity against Escherichia coli (DSM 116) and Enterococcus faecium (DSM 20477, DSM 17050) and no inhibition activity against Escherichia coli WT3 and Pseudomonas aeruginosa (DSM 19882). Results indicated, that tested strain was more active against Gram-positive bacteria in comparison with Gramnegative. Similar results found out also Silambarasan et al. (2012) in their study.

\section{CONCLUSION}

Selected actinomycete isolate (Streptomyces rishiriensis) showed significant antibiotic activity against the tested microorganisms, mostly against methicilinresistant Staphylococcus aures N315. Therefore, this isolate proves to be a promising isolate which can be further studied for its applications in producing important pharmaceutical compounds. The present study is mainly involved in the identification of this strain based on the cultural, morphological, physiological, biochemical and molecular methods. Further studies for characterization of secondary metabolites are currently in progress. It is expected that the current attempt for the isolation and characterization of actinobacteria from region Východná will be useful for the identification of novel antibiotics effective against various pathogens.

Acknowledgments: This work was supported by Microbial Strain Collection Group of Helmholtz Centre for Infection Research in Braunschweig, Germany and by VEGA 1/0476/13 and VEGA 1/0611/14.

\section{REFERENCES}

ALI, M. A., KEERA, A. A., HELMY, M. S., ABD-EL_NASSER, H. N., AHMED, K. A., EL-HENNAWI, H. M. 2011. Selection of pigment (melanin) production in Streptomyces and their application in printing and dyeing of wool fabrics. Research Journal of Chemical Sciences, 1(5), 22-28.

AMIRMOZAFFARI, N., VIZANEH, S. D., ISAZADEH, K., TAHERI, A. R. 2014. Isolation of actinomycetes producing antibacterial against methicilinresistant Staphylococcus aureus from soils of Astara region, Iran. Qom University of Medical Sciences Journal, 8(2). 59-68.

ANANSIRIWATTANA, W., TANASUPAWAT, S., AMNUOYPOL, S., SUWANBORIRUX, K. 2006. ) Identification and antimicrobial activities of actinomycetes from soils in Samed Island and geldanamycin from strain PC4-3. The Thai Journal of Pharmaceutical Sciences, 30, 49-56.

ANTONOVA-NIKOLOVA, S., STEFANOVA, V., YOCHEVA, L. 2006-2007. Taxonomic study of Streptomyces sp. strain 34-1. Journal of Culture Colletions, 5,(1), 10-15.

BASKARAN, R., VIJAYAKUMAR, R., MOHAN, P. M. 2011. Enrichment method for the isolation of bioactive actinomycetes from mangrove sediments of Andaman Islands, India. Malayasian Journal of Microbiology, 7(1), 26-32.

BERDY, J. 2005. Bioactive microbial metabolites: a personal view. Journal of Antibiotics. 58(1), 1-26. http://dx.doi.org/10.1038/ja.2005.1. 
BHARTI, A., KUMAR, V., GUSAIN, O., SINGH-BISHT, G. 2010. Antifungal activity of actinomycetes isolated from Garhwal region. Journal of Engineering an Technology Management, 2(2), 3-9.

CAI, Y., XUE, Q., CHEN, Z., ZHANG, R. 2009. Classification and salttolerance of actinomycetes in the Qinghai lake water and lakeside saline soil. Journal of Sustainable Development, 2(1). 107-110. http://dx.doi.org/10.5539/jsd.v2n1p107.

CLAUS, H., DECKER, H. 2006. Bacterial tyrosinase. Systematic and Applied Microbiology, 29, 3-14. http://dx.doi.org/10.1016/j.syapm.2005.07.012.

COOK, A. E. - MEYERS, P. R. 2003. Rapid identification of filamentous actinomycetes to the genus level using genus-specific 16S rRNA gene restriction fragment patterns. International Journal of Systematic and Evolutionary Microbiology, 53, 1907 - 1915. http://dx.doi.org/10.1099/ijs.0.02680-0.

CRAWFORD, D. L., LYNCH, J. M., WHIPPS, J. M., OUSLEY, M. A. 1993. Isolation and characterization of actinomycete antagonists of a fungal root pathogen. Applied and Environmental Microbiology, 59, 3899-3905.

DAS, A., BHATTACHARYA, S., HASSAN-MOHAMED A. Y., RAJAN, S. S 2014. In vitro antimicrobial activity and characterization of mangrove isolates of streptomycetes effective against bacteria and fungi of nosocomial origin Brazilian Archives of Biology and Technology, 57(3). http://dx.doi.org/10.1590/s1516-89132014005000006.

DASTAGER, S. G., WEN-JUN, L., DAYANAND, A., SHU-KUN, T., XINPEKNG, T., XIAO-YANG, Z., LI-HUA, X., CHENG-LIN, J. 2006. Separation, identification and analysis of pigment (melanin) production in Streptomyces African Journal of Biotechnology, 5(8), 1131-1134.

DEEPIKA, T. L., KANNABIRAN, K. 2009. A morphological, biochemical and biological studies of halophilic Streptomyces sp. isolated from saltpan environment. American Journal of Infectious Disease, 5(3), 207-213. http://dx.doi.org/10.3844/ajidsp.2009.207.213.

GOODFELLOW, M., WILLIAMS, S. T. 1993. Ecology of actinomycetes Annual Review of Microbiology, 37, 189-215. http://dx.doi.org/10.1146/annurev.mi.37.100183.001201.

HOLT, J. G. - KRIEG, N. R. - SNEATH, P. H. A. - STALEY, J. T. WILLIAMS, S. T. 1994. Bergey's Manual of Determinative Bacteriology. Baltimore: Williams and Wilkins. 787 p. ISBN 0-683-00603-7.

KHAN, S. T., TAMURA, T., TAKAGI, M., SHIN-YA, K. 2010. Streptomyces tateyamensis sp. nov., Streptomyces marinus sp. nov., isolated from the marine sponge Haliclona sp. International Journal of Systematic and Evolutionary Microbiology, 60(12), 2775-2779. http://dx.doi.org/10.1099/ijs.0.019869-0.

KORZENIEWSKA, E., FILIPKOWSKA, Z., GOTKOWSKA, PLACHTA, A., JANCZUKOWICZ, W., DIXON, B., CZULOWSKA, M. 2009. Determination of emitted airborne microorganisms from a BIO-PAK wastewater treatment plant. Water research, 43, 2841 - 2851. http://dx.doi.org/10.1016/j.watres.2009.03.050. KURTBOKE, D. I. 2005. Actinophages as indicator of actinomycete taxa in marine environments. Antonie van Leeuwenhoek, 87, 19-28. http://dx.doi.org/10.1007/s10482-004-6535-y.

KUTZNER, H. J. 1981. The family Streptomycetaceae. In STARR, M. P. STOLP, H., TRÜPPER, H. G., BALONS, A., SCHLEGEL, H. G.: The prokaryotes - A handbook on habitats, isolation and identification of bacteria Berlin: Springer Verlag, 2028-2090. ISBN 978-3-662-13187-9.

LOCCI, R. 1989. Streptomycetes and related genera. In WILLIAMS, S. T. SHARPE, M. E., HOLT, L. G. Bergey's Manual of Systematic Bacteriology. Baltimore: MD: Williams \&Wilkins, 2451-2505. ISBN 0683090615.

NAGAI, A., KHAN, S. T., TAMURA, T., TAKAGI, M., SHIN-YA, K. 2011 Streptomyces aomiensis sp. nov., isolated from a soil sample using the membrane-filter method. International Journal of Systematic and Evolutionary Microbiology, 61, 947-950. http://dx.doi.org/10.1099/ijs.0.020719-0.

NAINE, J., NASIMUNISLAM, N., VAISHNAVI, B., MOHANASRINIVASAN, V., SUBATHRA-DEVI, C. 2012. Isolation of soil actinomycetes inhabiting amrithi forest for the potential source of bioactive compounds. Asian Journal of Pharmacetutical and Clinical Research, 5(3), 189-192.

OSKAY, M., TAMER, Ü., AZERI, C. 2004. Antibacterial activity of some actinomycetes isolated from farming soils of Turkey. African Journal of Biotechnology, 3(9), 441-446.

PANDEY, A., SHUKLA, A., MAJUMDAR, S. K. 2005. Utilization of carbon and nitrogen sources by Streptomyces kanamyceticus M 27 for the production of an Antibacterial antibiotic. African Journal of Biotechnology, 4(9), 909-910.

PARASA, L. S., TUMATI, S. R., KUMAR, C. A., CHICURUPATI, S. P., RAO, G. S. 2011. In vitro antimicrobial activity of cashew (Anacardium occidentale, L.) nuts shell liquid against methicillin resistant Staphylococcus aureus (MRSA) clinical isolates. International Journal of Pharmacy and Pharmaceutical Sciences, 3, 436-440.

PATEL, J. D., PARMAR, M., PATEL, P., ROHIT, P., TAVIYAD, R., ANSARI, P., BHATTACHARYA, B., VYAS, D., KUMAR, V., SAHAY, N. S., SINGH, P. K. 2014. Dynamism of antimicrobial activity of actinomycetes - a case study from undisturbed microbial niche. Advances in Microbiology, 4, 324-334. http://dx.doi.org/10.4236/aim.2014.46039.

PRIDHAM, T. G., GOTTLIEB, D. 1948. The utilization of carbon compounds by some actinomycetales as an aid for species determination. Journal of Bacteriology, 56, 107-114.
RAHMAN, A., ZAHIDUL ISLAM, M., UL ISLAM, A. 2011. Antibacterial activities of actinomycete isolates collected from soils of Rajshahi, Bangladesh. Biotechnology Research International, 2011, 1-6. http://dx.doi.org/10.4061/2011/857925.

SAHIN, N., UGUR, A. 2003. Investigation of the antimicrobial activity of some Streptomyces isolates. Turkish Journal of Biology, 27, 79-84.

SINGH, S., KUMAR, P., GOPALAN, N., SHRIVASTAVA, B., KUHAD, R. C., CHAUDHARY, H. S. 2012. Isolation and partial characterization of actinomycetes with antimicrobial activity against multidrug resistant bacteria. Asian Pacific Journal of Tropical Biomedicine, S1147-S1150. http://dx.doi.org/10.1016/s2221-1691(12)60375-x.

RANA, S., SALAM, M. D. 2014. Antimicrobial potential of actinomycetes isolated from soil samples of Punjab, India. Journal of Microbiology \&Experimentation, 1(2), 1-6. http://dx.doi.org/10.15406/jmen.2014.01.00010.

SAMBROOK J. 2001. Molecular Cloning: A Laboratory Manual, Third Edition (3 volume set). New York: Cold Spring Harbor Laboratory Press. 2344 p. ISBN 0879695773.

SANGLIER, J. J., HAAG, H., HUCK, T. A., FEHR, T. 1993. Novel bioactive compounds from actinomycetes: a short review (1988-1992). Research in Microbiology, 144(8), 633-642. http://dx.doi.org/10.1016/0923-2508(93)90066b.

SHARMA, D., KAUR, T., CHADHA, B. S., KUMARI-MANHAS, R. 2011. Antimicrobial activity of actinomyetes against multidrug resistant Staphylococcus aureus, E. coli and various other pathogens. Tropical Journal of $\begin{array}{lll}\text { Pharmaceutical } & \text { Research, 10(6), 801-808. }\end{array}$ http://dx.doi.org/10.4314/tipr.v10i6.14.

SHIMIZU, M., NAKAGAWA, Y., SATO, Y., FURAMAI, T., AGARASHI, Y., ONAKA, H., YOSHIDA, R., KUNCH, H. 2000. Studies on endophytic actinomycetes Streptomyces sp. isolated from Rhododendron and its antimicrobial activity. Journal of General Plant Pathology, 66, 360-366. http://dx.doi.org/10.1007/pl00012978.

SHIRLING, E. B. - GOTTLIEB, D. 1966. Methods for characterization of Streptomycetes species. International Journal of Systematic Bacteriology, 16 (3), 313 - 340. http://dx.doi.org/10.1099/00207713-16-3-313.

SILAMBARASAN, S., KUMAR, E. P., MURUGAN, T., SARAVANAN, D. BALAGURUNATHAN, R. 2012. Antibacterial and antifungal activities of actinobacteria isolated from Rathnagiri hills. Journal of Applied Pharmaceutical Science, 2(10), 099-103. http://dx.doi.org/10.7324/japs.2012.21020.

SIVAKUMAR, K. 2001. Actinomycetes of an Indian mangrove (Pitchavaram) environment, PhD thesis. India: Annamalai University, p. 91.

SPADARI, C., ANTUNES, T., TEIXEIRA, R., MINOTTO, E., FUENTEFRIA, M., VAN DER SAND, S. 2013. Antifungal activity of actinobacteria against fungus isolates of clinical importance. Brazilian Journal of Biosciences, 11(4), 439-443.

SUNEETHA, V., KARTHICK, R., PRATHUSHA. 2011. Isolation and identification of Streptomyces ST1 and ST2 strains for Tsunami affected soils: Morphological and Biochemical studies. Journal of Oceanography and Marine Sciences, 2(4), 96-101.

SUTER, M. A. 1978. Isolierung und Charakterisierung von melanin-negativen mutanten aus Streptomyces glaucescens: thesis no. 6276. Switzerland: Eidgenossische Technische Hochschule Zurich.

THAKUR, D., YADAV, A., GOGOI, B. K., BORA, T. C. 2007. Isolation and screening of Streptomyces in soil of protected forest areas from the states of Assam and Tripura, India, for antimicrobial metabolites. Journal of Medical Mycology, 17, 242-249. http://dx.doi.org/10.1016/j.mycmed.2007.08.001.

VARGHESE, R., NISHAMOL, S., SUCHITHRA, R., MOHAMED HATHA, A A. 2012. Biochemical and physiological characteristics of actinomycetes isolated from high altitude Shola soils of tropical Montane forest. Indian Journal of Innovations and Developments. 1(3), 142-144

VĚTROVSKÝ, T., STEFFEn, K. T., BALDRIAN, P. 2014. Potential of cometabolic transformation of polysaccharide and lignin in lignocellulose by soil Actinobacteria. PlosOne, 9(2). http://dx.doi.org/10.1371/journal.pone.0089108.

VINAROV, A. U., ROBYSHEVA, Z. N., SIDORENKO, T. E., DIRINA, E. N. 2002. Biotechnology of pigment melanin. Proceeding of the 1 st international congress 'biotechnology-state of the art and prospects of development', p. 96 http://dx.doi.org/10.1023/b:abim.0000025960.78126.65.

VÍTEZOVÁ, M. 2013. Characterisation of actinomycetes community from the heavy metals-pollute soil. Acta Universitates AgricultuEa et Silviculturae mendelianae brunensis, $61, \quad 1471-1478$ http://dx.doi.org/10.11118/actaun201361051471

WINK, J., BARTOSCHEK, S., BATZER, A., RENARD, S. 2013. Methods for the activation of silent genes in microorganisms. Patent no: WO/2013/171158. 